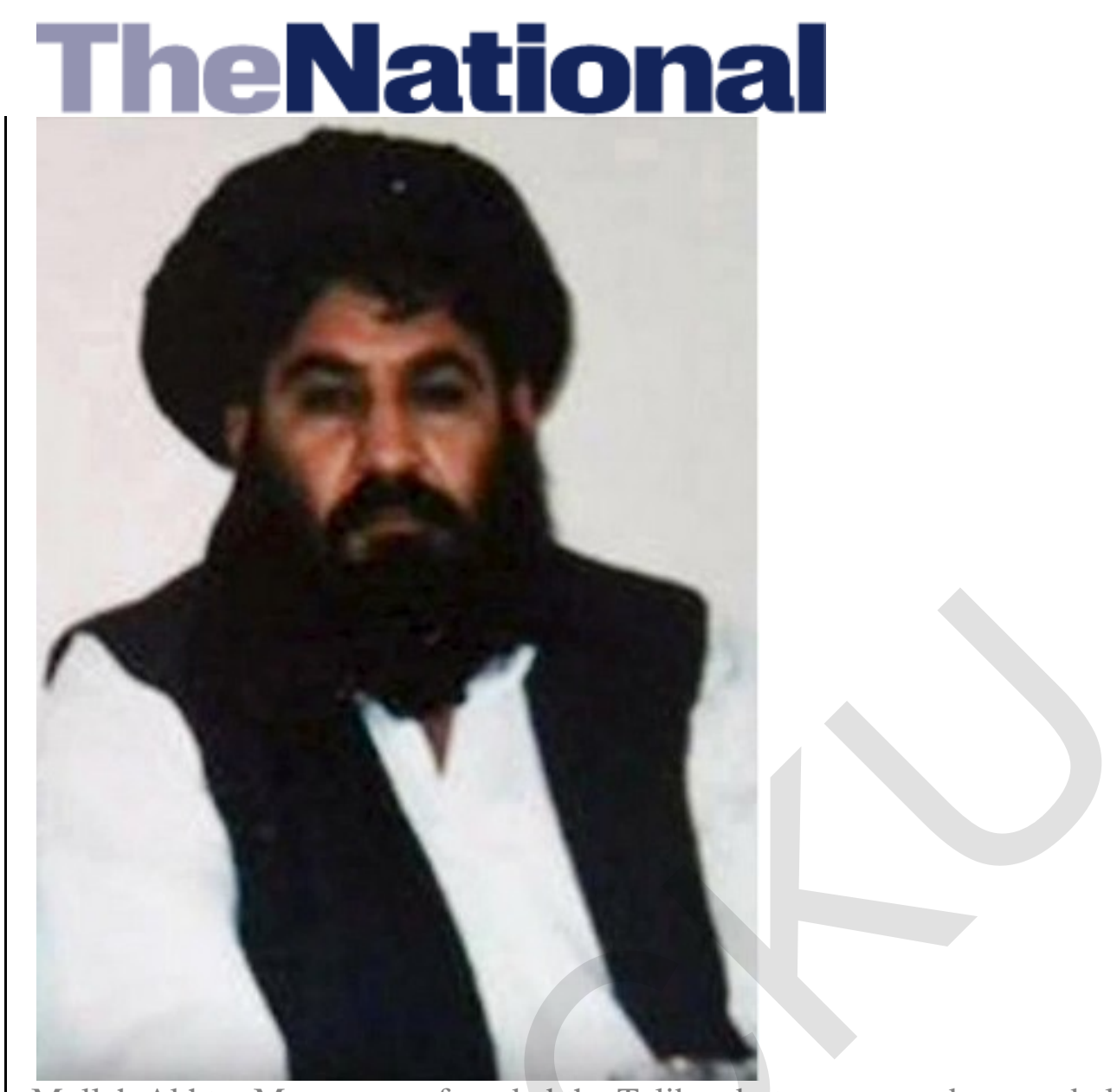

Mullah Akhtar Mansour co-founded the Taliban but some members are believed to be unhappy with him and have rallied around former leader Mullah Omar's son, Yaqoob, instead. Taliban Handout/Reuters

\title{
Life and death of Mullah Omar cast a long shadow over Afghanistan
}

Chris Sands and Fazelminallah Qazizai

August 5, 2015 Updated: August 5, 2015 01:08 AM

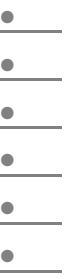

$\underline{\text { Related }}$ 




-

- Mysterious suicide attack highlights ISIL's reach in eastern Afghanistan

- Afghan Taliban leader injured in internal firefight

- Afghans consider siding with Taliban as bloodshed rises in north

- Ex-Taliban leader's family declares support for new leader Mansour

- Pakistan liberates Taliban 'no-go zones' in Karachi

Topics:

- Afghanistan

KABUL // The head of the Taliban's political office in Qatar has resigned as the life and death of the movement's spiritual leader continue to cast a long shadow over Afghanistan.

It was confirmed last week that Mullah Mohammed Omar died some time ago, though the exact circumstances remain disputed. Since then the prospect of peace talks has been thrown into confusion and reports of infighting have emerged on a daily basis amid apparent unhappiness within the movement at the choice of his successor.

In the latest development, the head of the Taliban's political office, Tayyab Agha, stepped down on Monday and said he would not support any side in the ongoing dispute. The Afghan government, meanwhile, appears divided over the best way forward - with some officials seemingly intent on exploiting any weakness in the insurgency and determined to crush it once and for all.

Watching this unfold, former Taliban officials are unsure exactly how the militants will react to the threat of factionalism and posturing from long-time enemies. But in a series of interviews with The National in Kabul, they continued to speak with admiration for their late leader.

Mawlawi Qalamuddin, who is in his 60s, held a memorial service in the city on Saturday, which was attended by dozens of Afghans, including prominent elders. It was not "just a prayer ceremony for Mullah Omar," he said. "It was about the death of Mullah Omar and the issue of peace."

The Taliban emerged in Afghanistan as an antidote to the chaos that developed in the wake of the 1989 Soviet withdrawal. The movement's strict interpretation of Sharia and the stability it brought quickly found favour among much of the population, who were tired of rival mujaheddin factions tearing the country apart.

According to a biography published on the Taliban's website earlier this year, Mullah Omar was born in 1960 in the southern province of Kandahar. He fought in the anti-Soviet resistance, then 
opened a religious school when the Russians withdrew. Only after security deteriorated did he take up arms again.

The Taliban captured Kabul in 1996 and ruled over most of the country until the 2001 US-led invasion. It was a period of tough social restrictions but relative safety for many Afghans, with corporal and capital punishments carried out in public to deter criminals.

During that time, Mawlawi Qalamuddin ran the ministry for the promotion of virtue and prevention of vice, the government's religious police. He first met Mullah Omar on an official trip to Kandahar and his initial impressions were of a pious and austere man, sitting on a Pashtun bed in the kind of clothes worn by villagers across the south.

He was later among a group of ministers rebuked by Mullah Omar for forgetting their humble origins. According to him, Mullah Omar said: "If the doors to your ministry are blocked, if you don't solve the problems of the nation, if you are proud of yourselves and arrogant, then you will not be ministers anymore. Instead, I will make your guards ministers."

News of Mullah Omar's death came after a Taliban splinter group claimed that rivals within the movement had killed him. The Afghan government then publicly said that he had "died suspiciously" in April 2013 in a hospital in the Pakistani city of Karachi, without elaborating on the cause.

Similar claims in the past have always been denied, retracted or ignored, but this time the Taliban confirmed that he was dead. Without saying when or exactly where, it said that he had died from an unspecified illness having never left Afghanistan. 